\title{
Research on The Cultivation Mode of E-commerce Application Talent Based on Position Requirement
}

\author{
Wenling Liu \\ School of Information Science and Technology \\ Taishan University \\ Taian, China \\ 1002653637@qq.com
}

\author{
Haiyan Bian \\ School of Information Science and Technology \\ Taishan University \\ Taian, China \\ xkxhaiyan@163.com
}

\begin{abstract}
In order to solve the difficult of recruitment and job search in e-commerce major, we need to reform the talent training model of e-commerce in the application universities. In this paper, firstly, we classify e-commerce enterprises in order to clear working direction of different types of enterprises. Secondly, we analyze the ken and ability requirements of positions in different categories. In the end, we analyze the cultivation mode of application talents from the aspects of curriculum setting and teaching practice.
\end{abstract}

Keywords - talent cultivation; e-commerce position; enterprise analysis

\section{INTRODUCTION}

E-commerce as a new business model has become the focus of the national 13th five-year plan [1]. The concept of Internet Plus has expanding the application of e-commerce. And the requirement of e-commerce talents is growing. However, according to statistics, employment rate of e-commerce undergraduate major is lower than the overall average [2]. E-commerce students face the difficult of recruitment and job search. The main reason for this situation is that there is a big gap between the content of the teaching reform of e-commerce courses in application undergraduate universities and the actual requirements of e-commerce enterprises. Therefore, the training of talents in application universities should be combined with job positions, requirements and capabilities.

Firstly, this paper classifies the e-commerce enterprises and e-commerce positions, and identifies the scope of knowledge and capacity requirements among different types of e-commerce business. Secondly, we set up talent cultivation mode of e-commerce major in curriculum setting and teaching practice these two aspects to cultivate e-commerce application talents.

\section{E-COMMERCE ENTERPRISE ANALYSIS}

E-commerce major of application undergraduate universities cultivates the senior specialized personnel. The students should not only master the knowledge of e-commerce, management, economy and law, but also have the practical operation of ecommerce. Students can work in the relevant state enterprises, institutions, government departments, especially private enterprises and e-commerce teaching, research work etc..

In this paper, according to the research and analysis of e-commerce enterprise, e-commerce enterprises can be divided into ecommerce application enterprises, e-commerce services enterprises, e-commerce professional enterprises and e-commerce thirdparty service platform enterprises [6]. As shown in Table 1.

TABLE I. ENTERPRISE CLASSIFICATION

\begin{tabular}{|l|l|}
\hline \multicolumn{1}{|c|}{ Enterprise Category } & \multicolumn{1}{c|}{ Meaning } \\
\hline $\begin{array}{l}\text { e-commerce application } \\
\text { enterprise }\end{array}$ & $\begin{array}{l}\text { E-commerce application enterprise refers to the national economy of various } \\
\text { industries which carries out e-commerce business, such as Huawei, ZTE, etc.. } \\
\text { The direct reasons why these enterprises carry out e-commerce business are to } \\
\text { reduce operating costs, to broaden sales channels, and to develop network } \\
\text { marketing. }\end{array}$ \\
\hline $\begin{array}{l}\text { e-commerce } \\
\text { enterprise }\end{array}$ & $\begin{array}{l}\text { E-commerce services enterprise is a kind of emerging services industry which } \\
\text { provides network-based transaction services, business outsourcing services and } \\
\text { information technology outsourcing services. Broadly speaking, all enterprises } \\
\text { belonging to e-commerce services should belong to e-commerce service } \\
\text { enterprises. }\end{array}$ \\
\hline
\end{tabular}


TABLE I., cont. ENTERPRISE CLASSIFICATION

\begin{tabular}{|l|l|}
\hline \multicolumn{1}{|c|}{ Enterprise Category } & \multicolumn{1}{|c|}{ Meaning } \\
\hline $\begin{array}{l}\text { e-commerce professional } \\
\text { enterprise }\end{array}$ & $\begin{array}{l}\text { E-commerce professional enterprise refers to the enterprise that transaction with } \\
\text { other enterprises, units or individuals for products or services only through the } \\
\text { Internet, such as Joyo, Dangdang, etc.. Compared with non-professional } \\
\text { enterprises, e-commerce professional enterprise providing all the services in the } \\
\text { form of network and e-commerce depends on the Internet highly. }\end{array}$ \\
\hline $\begin{array}{l}\text { e-commerce third-party } \\
\text { service platform enterprise }\end{array}$ & $\begin{array}{l}\text { E-commerce third-party service platform Enterprise refers to the kind of } \\
\text { enterprise that provides business platform for other enterprises, units or } \\
\text { individuals to carry out e-commerce transactions or services, such as Alibaba } \\
\text { and Taobao. The outstanding characteristics of these enterprises is not directly } \\
\text { to do their own e-commerce, but to provide professional services for other } \\
\text { enterprises to carry out e-commerce. }\end{array}$ \\
\hline
\end{tabular}

\section{E-COMMERCE Professional Position ANALysis}

With the development of internet, recruitment website becomes main employment method for students. Recruitment advertising is the most intuitive performance of business needs for talents, which includes position responsibilities and skills requirements. According to the information on the recruitment websites of e-commerce and the research on e-commerce enterprises, we divide e-commerce position into three types, including technical position, business position and comprehensive position. The technical position includes website development, e-commerce art, search engine optimization, UI designer, data analysis, etc.; business position includes network marketing, website promotion, e-commerce consultant, website operation etc.; comprehensive position includes e-commerce platform for integrated management, e-commerce integrated management. As shown in Table 2.

Technical talents are required solid computing ability and should be able to understand the requirements of the business process and the consumer psyche. The difference between business type and traditional business type is that business talents are users and services of online virtual markets. Comprehensive talents are required to master comprehensive knowledge and skills, and need more practice on the basis of school culture.

TABLE II. E-COMMERCE PROFESSIONAL POSITION AND ABILITY

\begin{tabular}{|c|c|c|}
\hline Category & Position & Knowledge and Ability \\
\hline \multirow{6}{*}{ technical position } & Website development & $\begin{array}{l}\text { Java, HTML and other programming languages, } \\
\text { SQL server / oracle and other databases, } \\
\text { Dreamweaver / flash and other web production } \\
\text { tools, firewall and network security, data structure }\end{array}$ \\
\hline & E-commerce artwork & $\begin{array}{l}\text { Photoshop, Dreamweaver, flash, art design, web } \\
\text { design, HTML / CSS }\end{array}$ \\
\hline & Search Engine Optimization & $\begin{array}{l}\text { Search engine ranking technology, the use of search } \\
\text { engines to promote the site, the use of SEO tools }\end{array}$ \\
\hline & UI designer & $\begin{array}{l}\text { Photoshop / Dreamweaver / flash and other design } \\
\text { software, graphic design, web design }\end{array}$ \\
\hline & Data Analyst & $\begin{array}{l}\text { Data mining, database, excel / spss and other } \\
\text { analysis software, SQL query }\end{array}$ \\
\hline & Website planning & $\begin{array}{l}\text { Office software, copy planning and writing, } \\
\text { Dreamweaver and other web production tools }\end{array}$ \\
\hline \multirow{4}{*}{ business position } & Network marketing & $\begin{array}{l}\text { The capability of using network sales platform, } \\
\text { communications software, computer and Internet } \\
\text { and writing skills }\end{array}$ \\
\hline & Website promotion & $\begin{array}{l}\text { Network promotion methods and tools, search } \\
\text { engine ranking technology, data analysis capability, } \\
\text { network marketing tools and strategies }\end{array}$ \\
\hline & E-commerce consultant & $\begin{array}{l}\text { Network marketing planning, sales channels } \\
\text { improving }\end{array}$ \\
\hline & Website operation & $\begin{array}{l}\text { Public number operation, channel planning, } \\
\text { information management, channel promotion, } \\
\text { customer management }\end{array}$ \\
\hline \multirow{2}{*}{$\begin{array}{l}\text { comprehensive } \\
\text { position }\end{array}$} & $\begin{array}{l}\text { E-commerce platform for } \\
\text { integrated management }\end{array}$ & $\begin{array}{l}\text { Computer and network basic knowledge and skills, } \\
\text { project management }\end{array}$ \\
\hline & $\begin{array}{l}\text { E-commerce } \\
\text { management }\end{array}$ & $\begin{array}{l}\text { E-commerce overall planning, construction, } \\
\text { operation and management }\end{array}$ \\
\hline
\end{tabular}




\section{E-COMMERCE TALENT Cultivation Mode}

\section{A. Curriculum Setting}

For the application oriented university, graduates need to meet the market for job creation. So, in the course settings, we need to surround this target with talent. The core curriculums of the technical position should include Introduction of Computer Science, Network Programming Basics, E-commerce System Analysis and Design, Management Information System, Design Basis, Shop Designer, Web Design Basics, Database Technology and Application and other courses; the core curriculums of business position should include Network Marketing, Logistics and Supply Chain Management, Search Engine Technology, Mobile E-commerce, Cross-border E-commerce, Network Economics, Process Management, Data Marketing and other course; students of comprehensive position are required to master both of these kinds of knowledge, and they also needs to have the integrated skills of other positions, including office automation software, basic professional(learning skill, the spirit of professionalism etc.), interpersonal relationship(teamwork, speech ability etc.) and professional qualifications[4]. These knowledge and skills need to be practiced and learned in long-term learning.

\section{B. Teaching Practice}

The teaching practice system of the e-commerce major should include three aspects, including classroom training, platform practice, and external internship base practice [5].

Classroom training is a learning project in the classroom hours and it is a project to mimic the business environment. Through this training, students should be able to make initial decisions about career roles and establish professional emotions. Students, for example, are engaged in e-commerce careers, and the practice is explored from the perspective of e-commerce professionals. It can help students learn about e-commerce careers, gain professional experience and build emotions. In addition, the e-commerce major requires a lot of training projects to be done outside the classroom. Schools should develop entrepreneurial platforms which facilitate students practice. These platforms will not only be able to complete something projects like the classroom, but they can expand further. The purpose of this practice is to improve the level of business and professional standards of students, grind the students into professionals in order to make students gain the basic ability. Extracurricular enterprises can provide real business environments for actual businesses. Students gain knowledge while they work on the platform. In other words, the goal of such events is to get the job done. Through these practices, there are a lot of exceptional talents to be able to refine.

\section{CONCLUSIONS}

At present, e-commerce is developing rapidly which follows the rapid increase of the demand for the application e-commerce talent. Application universities should combine the training model to adjust the knowledge and capacity for the different types of e-commerce positions. It should be oriented to employment and needs to clarify the main body of personnel training and the status of each subject. In the teaching process, we should pay attention to the combination of teaching and practice, the construction of practical curriculum system and the innovation of means. In the end, it can create a good foundation for employment and solve the employment problem of e-commerce major.

\section{REFERENCES}

[1] Zhihong Deng, and Bingjia Shao, Study on E-commerce Posts' core skills demands in Chinese enterprises. Experimental technology and management. Vol.29, pp.136-140, Nov.2012.

[2] Tingting Chen, Exploration on the reform of e-commerce customer service course based on position requirement. E-commerce. Vol.20, pp.42-43, 2016.

[3] Tao Hu, and Tingjie Lv, Exploration on the reform of e-commerce customer service course based on position requirement. Research and exploration in laboratory. Vol.27, pp.134-137, Mar. 2008.

[4] Yiwei Zhao, and Yanqing Du. Research on the training mode of talents cultivation for e-commerce application facing position requirement. Journal of higher education. Vol.5, pp.51-52, 2017.

[5] Haiyan Liu, and Lijie Zhuo, A new model of the development of e-commerce major. Economic Research. Vol.1, pp.66-67, 2014.

[6] Information on https:// zm12.sm-tc.cn/ 